\title{
Effects of weather and other factors on milk production in the Churra dairy sheep breed
}

\author{
Manuel Gonzalez-Ronquillo $^{\mathrm{a}}$ (D) | José-Alfonso Abecia ${ }^{\mathrm{b} *}$ (iD) | Ricardo Gómez ${ }^{\mathrm{c}}$ | Carlos Palacios ${ }^{\mathrm{c}}$ \\ a Universidad Autónoma del Estado de México, Facultad de Medicina Veterinaria y Zootecnia. Instituto Literario 100 Ote., 50000 , Toluca, Estado de Mexico, \\ Mexico. \\ ${ }^{b}$ Instituto Universitario de Investigación en Ciencias Ambientales, Facultad de Veterinaria, Miguel Servet 177, 50013, Zaragoza, Spain. \\ 'Departamento de Construcción y Agronomía, Área de Producción Animal de la Facultad de Ciencias Agrarias y Ambientales, Filiberto Villalobos, 37007, \\ Salamanca, Spain.
}

Corresponding author: alf@unizar.es

\begin{abstract}
The objective of this study was to investigate the influence of meteorological and other factors on the quality and quantity of milk of the Spanish Churra sheep breed, based on an analysis of 359,808 milk controls from 9,904 ewes on 15 farms in 8 years. Daily milk yield (DMY), fat, protein, and lactose (\%), and somatic cell count (SCC) data were obtained from monthly alternating milk controls. Mean, maximum, and minimum temperatures $(\mathrm{T})\left({ }^{\circ} \mathrm{C}\right)$, mean relative humidity $(\mathrm{RH})(\%)$, wind speed (WS, $\mathrm{m} / \mathrm{s})$, mean solar radiation $\left(\mathrm{SR}, \mathrm{MJ} / \mathrm{m}^{2}\right)$, and total rainfall $(\mathrm{RF}, \mathrm{mm})$ on the day before each milk control day were documented. Year, farm, number of lambing and stage of lactation, and all of the meteorological factors had a significant $(P<0.0001)$ effect on DMY and milk quality. DMY and SCC differed among seasons $(P<0.001)$, and maximum DMY and minimum SCC occurred in spring, and minimum DMY and maximum SCC occurred in autumn. Fat, protein, and lactose content differed significantly $(P<0.001)$ among seasons, and fat and protein contents were highest in autumn. DMY was highest in the second lambing of the ewe and steadily declined in subsequent lambings. SCC increased significantly from the first to the 10th lambing of the ewe. DMY, SCC, and fat content differed significantly $(P<0.001)$ among years. In conclusion, meteorological conditions had a significant effect on milk quality and production in Churra sheep conditions in a season-dependent manner such that factors such as temperature had the opposite effect on milk production in hot and cold seasons.
\end{abstract}

Keywords fat, ovine, protein, season, temperature

\section{Introduction}

Milk fat and protein concentrations, and somatic cell count (SCC) have a significant effect on the technical and coagulation properties of milk, thus having a major impact on the yield and quality in the production of dairy products. Animal diet is one of the main factors that affect milk yield and composition (Nudda et al 2019); however, environmental factors such as ambient temperature (T), relative humidity $(\mathrm{RH})$, wind speed (WS), solar radiation (SR), and rainfall (RF) can influence the welfare of animals and, therefore, can influence the production and chemical composition of milk (Silanikove 2000).

Sheep are one of the livestock species that are most tolerant of climatic extremes, especially high ambient temperatures. The climate in the Mediterranean region is characterized by hot, dry summers and cool, wet winters; however, the ambient $T$ often can exceed the thermoneutral zone of sheep $\left(5{ }^{\circ} \mathrm{C}-25{ }^{\circ} \mathrm{C}\right.$ ) (Curtis 1983). T outside the thermoneutral zone can affect the physiological and production performance of lactating dairy sheep, which are the causes of significant losses in livestock production (Das et al 2016; Sejian et al 2018; Mylostyvyi and Chernenko 2019); however, in addition to $\mathrm{T}$, other factors can contribute to reduced milk yields. $\mathrm{RH}, \mathrm{WS}$, and SR can significantly affect animal physiology through their effects on thermoregulation
(Abdela et al 2016, Laporta et al 2017). For small ruminants, Caroprese (2011) advised reducing their sun exposure by increasing the amount of shaded area to reduce SR heat and stress, which affects milk production. Conversely, cold T harms the Manchega dairy sheep breed (Ramón et al 2016) and $T$ has a positive correlation with milk production (Abecia et al 2017).

In conditions of $\mathrm{T}$ and humidity stress, dairy cattle have reduced milk production, and the milk has reduced fat and increased SCC, which is most marked in the oldest animals (Nasr et al 2017). Although there is no published evidence that ambient $T$ directly affects udder health, there is evidence that it can interact with other predisposing conditions to affect milk production (Sevi and Caroprese 2012). Milk yield and milk composition can indicate animal well-being because they are affected by high $\mathrm{T}$ (Behera et al 2017).

Primarily, sheep milk is used in cheese production and, to produce high-quality cheese, milk that has high fat and protein content is desired. This study examined the relationships between meteorological conditions and the production and chemical composition of milk from the Spanish Churra dairy sheep breed in a Mediterranean continental climate. Besides, the effects of other factors including farm, year, number of parturitions, and stage of 
lactation, on milk production and chemical composition were evaluated.

\section{Materials and Methods}

\subsection{Animal management and milk records}

The analysis was based on 359,808 individual milk controls recorded during 687 different days, from 9,904 Churra ewes on 15 farms in eight years in Castilla y León, in the northern Spanish plateau $\left(41^{\circ} \mathrm{N}\right)$. Milk yield records were recorded by volumetric meters that were integrated into the milking system, and milk production was calculated by alternating between morning and afternoon records (ICAR 2016). Daily milk yield (DMY) was calculated by the approved official milk control method (ICAR 2016), which is based on the following formula:

DMY $=($ Registered milk * 24) / (Time between milk records)

Milk production per month and total lactation were calculated based on the method of ICAR, which uses alternating monthly controls (ICAR 2016).

The farms followed standardized management procedures, especially those involving nutrition and milking systems; specifically, ewes were raised in a semi-extensive production system and, in the first month of life, lambs remained with their mothers in the barns, with ewes put out to graze native grasses (Ballico spp. and weeds) for $10 \mathrm{~h}$ in spring and summer, and for $8 \mathrm{~h}$ in autumn and winter. Ewe diets were supplemented with a unifeed mixture of forage and concentrates, which were of three types: high milk production (first two months postpartum), medium production (three months), and low production (last two months of lactation). Ewes were mated five months postpartum, which produced three lambings every two years.

The data were from a pre-existing database, so approval from the ethics committee was not a prerequisite for this study. The study met the Spanish Policy for Animal Protection RD1201/05, which meets the European Union Directive 2010/63 on the protection of animals used for experimental and other scientific purposes.

\subsection{Milk analysis}

Milk was at the Interprofessional Laboratory of Milk Quality of Castilla y León (Palencia, Spain), and included analyses of fat, protein, and lactose content (\%), and SCC. The analysis of the chemical composition of milk followed the IDF Standard 020-5 (IDF 2010) for protein, the FIL 105 (IDF 2008) for fat, and the IDF 79-1.2/ISO 5765-1.2 (IDF 2002) for lactose content. To estimate SCC, an aliquot of the milk samples was preserved in bronopol $(0.1 \%)$ and analyzed by a Fossomatic 5000 (Foss Electric, Hillerød, Denmark), which had been calibrated with known standards, in the Analysis Service Laboratory of the Animal Breeding and Reproduction Centre (CENSYRA) in León (Spain). Milk samples were analyzed while at $4-6{ }^{\circ} \mathrm{C}$.

\subsection{Meteorological variables}

The meteorological data were collected at the weather stations of the Agroclimatic Information System for Irrigation of Spain (SiAR) that were closest to the farms involved in the study. The data were collected by a thermohygrometer (Rotronic HC2 S3, Bassersdorf, Switzerland), anemovelette (Young 05103, Traverse City, Michigan, USA), a pyranometer (Campbell Scientific Skye SP1110, Barcelona, Spain), a tipping bucket rain gauge (Campbell Scientific ARG100, Edmonton, Canada), and a datalogger (Campbell Scientific CR10X, Barcelona, Spain). Mean, maximum (max), and minimum (min) ambient $\mathrm{T}\left({ }^{\circ} \mathrm{C}\right)$, mean RH (\%), WS (m/s), mean SR (MJ/m²), and total RF (mm) on the day before each milk control were used.

\subsection{Statistical analyses}

Weather variables were converted to categorical variables (dummy variables), with the median value of each continuous meteorological variable as the cut-off point ( 0 if below the median, 1 if above the median), and each factor was distributed between two percentile-groups ( $\leq 50 \%$ and $>50 \%$ ) (Statistical Package for Social Sciences (SPSS) software, IBM, 2017). To assess the significance of the effects of nonmeteorological (year, farm, season, number of lambing, and monthly control) and meteorological factors on DMY and milk chemical composition the data were subjected to a multifactorial ANOVA in the General Linear Model (GLM) procedure in SPSS. The general representation of the model is as follows: $y=x b+e$, where $y$ is $N \times 1$ vector of records, $b$ denotes the fixed effect in the model within the association matrix $x$, as follows: farm (1-15), year (2008-2016), number of lambing (1-10), number of monthly milk control (1-10), and "0-1" for the meteorological factors based on the percentile group, and animal and the residual were considered random effects; and e is the vector of residual effects An ANOVA was performed for each meteorological season and factor. To insure a normal distribution, the SCC data were logtransformed ( $\log 10)$.

\section{Results}

Meteorological conditions in the region of the 15 farms differed significantly $(P<0.001)$ among seasons (Figure 1). Mean ( \pm S.E.M.) DMY, fat, protein, lactose, and SCC were $1.25 \pm 0.01 \mathrm{l} /$ day, $6.31 \pm 0.01 \%, 5.28 \pm 0.01 \%, 4.86 \pm 0.01 \%$, and $743,915 \pm 405$ cells/ml, respectively. Year, farm, number of lambing, number of milk control, and each of the meteorological factors had a significant $(P<0.0001)$ effect on DMY and milk quality (Table 1), except for SCC, which was not affected by the number of control. T in summer and autumn did not have a significant effect on DMY or SCC; WS had a significant $(P<0.0001)$ effect on DMY, fat, protein, and lactose content in spring and summer, and RF had a significant $(P<0.0001)$ effect on DMY and milk chemical composition, except protein content, in autumn, and on SCC in winter. 
Table 1 Matrix of the significance of the effects of non-meteorological (year, farm, number of lambing and number of monthly control) and meteorological factors on daily milk yield (DMY, L/day), fat, protein, and lactose content (\%), and somatic cell count (SCC, cells/ml) of milk from Churra sheep on 15 farms in Castilla y León, Spain (number of controls).

\begin{tabular}{|c|c|c|c|c|c|c|c|c|c|c|c|c|c|c|c|c|c|c|c|c|}
\hline \multirow[t]{2}{*}{ Item } & \multicolumn{4}{|c|}{ DMY, L/day } & \multicolumn{4}{|c|}{ \% Fat } & \multicolumn{4}{|c|}{ \% Protein } & \multicolumn{4}{|c|}{ \% Lactose } & \multicolumn{4}{|c|}{$\mathrm{SCC}$, cells $/ \mathrm{ml}$} \\
\hline & Spr & Sum & Aut & Win & Spr & Sum & Aut & Win & Spr & Sum & Aut & Win & Spr & Sum & Aut & Win & Spr & Sum & Aut & Win \\
\hline & $(125,851)$ & $(84,866)$ & $(66,964)$ & $(82,127)$ & & & & & & & & & & & & & & & & \\
\hline Year & 0.0001 & 0.0001 & 0.0001 & 0.0001 & 0.0001 & 0.0001 & 0.0001 & 0.0001 & 0.0001 & 0.0001 & 0.0001 & 0.0001 & 0.0001 & 0.0001 & 0.0001 & 0.0001 & 0.0001 & 0.0001 & 0.0001 & 0.0001 \\
\hline Farm & 0.0001 & 0.0001 & 0.0001 & 0.0001 & 0.0001 & 0.0001 & 0.0001 & 0.0001 & 0.0001 & 0.0001 & 0.0001 & 0.0001 & 0.0001 & 0.0001 & 0.0001 & 0.0001 & 0.0001 & 0.0001 & 0.0001 & 0.0001 \\
\hline Lambing & 0.0001 & 0.0001 & 0.0001 & 0.0001 & 0.0001 & 0.0001 & 0.0001 & 0.0001 & 0.0001 & 0.0001 & 0.0001 & 0.0001 & 0.0001 & 0.0001 & 0.0001 & 0.0001 & 0.0001 & 0.0001 & 0.0001 & 0.0001 \\
\hline Control & 0.0001 & 0.0001 & 0.0001 & 0.0001 & 0.0001 & 0.0001 & 0.0001 & 0.0001 & 0.0001 & 0.0001 & 0.0001 & 0.0001 & 0.0001 & 0.0001 & 0.0001 & 0.0001 & 0.959 & 0.542 & 0.344 & 0.222 \\
\hline Mean T & 0.023 & 0.689 & 0.850 & 0.0001 & 0.0001 & 0.0001 & 0.595 & 0.394 & 0.0001 & 0.0001 & 0.0001 & 0.0001 & 0.0001 & 0.0001 & 0.010 & 0.0001 & 0.029 & 0.092 & 0.865 & 0.033 \\
\hline $\operatorname{Max} T$ & 0.0001 & 0.0001 & 0.067 & 0.0001 & 0.0001 & 0.791 & 0.0001 & 0.0001 & 0.0001 & 0.038 & 0.001 & 0.0001 & 0.163 & 0.002 & 0.036 & 0.0001 & 0.002 & 0.178 & 0.436 & 0.013 \\
\hline $\operatorname{Min} T$ & 0.0001 & 0.0001 & 0.001 & 0.0001 & 0.391 & 0.0001 & 0.385 & 0.0001 & 0.0001 & 0.0001 & 0.040 & 0.0001 & 0.014 & 0.0001 & 0.501 & 0.0001 & 0.235 & 0.0001 & 0.537 & 0.0001 \\
\hline $\mathrm{RH}$ & 0.024 & 0.0001 & 0.0001 & 0.0001 & 0.111 & 0.0001 & 0.004 & 0.0001 & 0.0001 & 0.0001 & 0.0001 & 0.0001 & 0.0001 & 0.0001 & 0.0001 & 0.0001 & 0.0001 & 0.0001 & 0.488 & 0.961 \\
\hline WS & 0.0001 & 0.0001 & 0.0001 & 0.0001 & 0.0001 & 0.0001 & 0.0001 & 0.0001 & 0.0001 & 0.0001 & 0.180 & 0.134 & 0.0001 & 0.0001 & 0.267 & 0.021 & 0.079 & 0.001 & 0.0001 & 0.018 \\
\hline SR & 0.026 & 0.0001 & 0.066 & 0.0001 & 0.0001 & 0.175 & 0.0001 & 0.0001 & 0.011 & 0.0001 & 0.0001 & 0.0001 & 0.298 & 0.0001 & 0.0001 & 0.080 & 0.005 & 0.449 & 0.0001 & 0.0001 \\
\hline $\mathrm{RF}$ & 0.0001 & 0.0001 & 0.001 & 0.0001 & 0.0001 & 0.0001 & 0.001 & 0.0001 & 0.0001 & 0.0001 & 0.704 & 0.0001 & 0.0001 & 0.0001 & 0.0001 & 0.0001 & 0.0001 & 0.0001 & .0001 & 0.369 \\
\hline
\end{tabular}

Year season: Spring, Spr; Summer, Sum; Autumn, Aut; Winter, Win; Temperature, T ( $\left.{ }^{\circ} \mathrm{C}\right)$; Relative Humidity, RH, (\%); WS (Wind Speed. m/s); SR: Solar Radiation (MJ/m²); RF, rainfall (mm) 
DMY and SCC differed significantly $(P<0.001)$ among seasons; maximum DMY and minimum SCC occurred in spring, and minimum DMY and maximum SCC occurred in autumn (Figure 2). The fat, protein, and lactose content of milk differed significantly $(P<0.001)$ among seasons, and fat and protein percentages were highest in autumn (Figure 2). DMY was highest in the second lambing of the ewe and steadily decreased in subsequent lambings; SCC increased significantly from the first to the 10th lambing of the ewe (Figure 3). The fat content of the milk increased slightly with each successive lambing, and protein and lactose percentages were stable throughout an ewe's lambings (Figure 3). DMY, SCC, and fat content differed significantly ( $P$ $<0.001$ ) among years, but the percentages of protein and lactose remained stable throughout the nine years (Figure 4). Finally, DMY and fat percentage significantly fell and rose, respectively, from the first month after lambing to the 10th (Figure 5). However, SCC was not affected by the month of control.

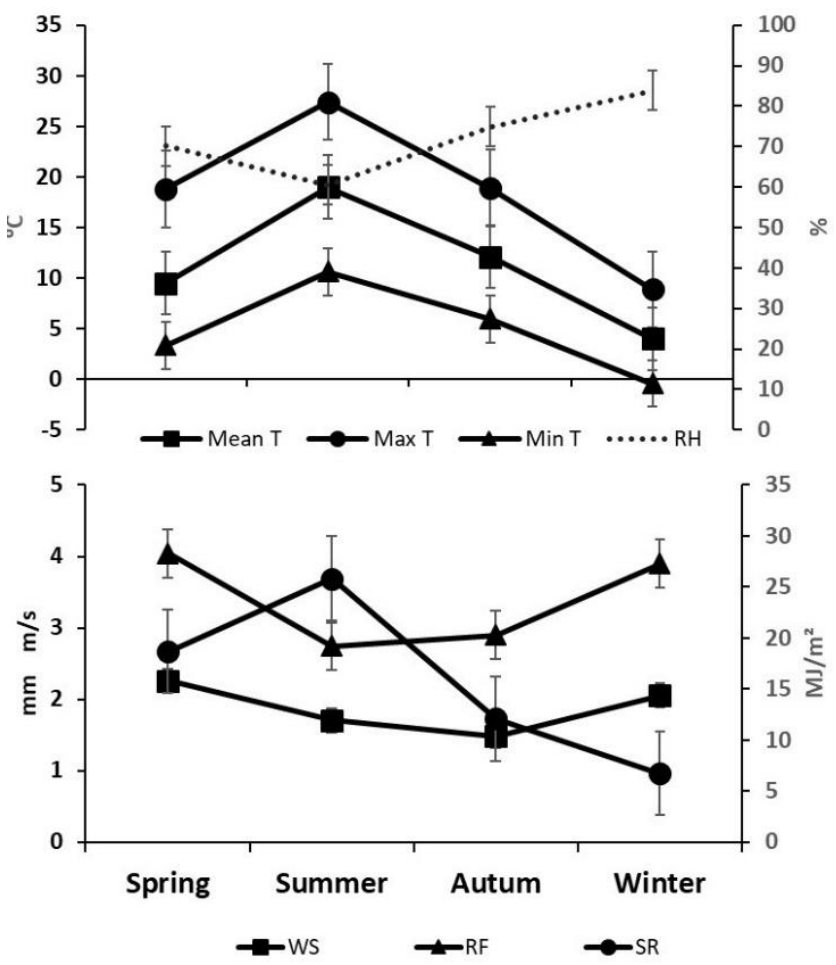

Figure 1 Mean ( \pm S.E.M.) meteorological conditions at weather stations nearest to 15 Churra dairy sheep farms in Castilla y León, Spain, on the day before milk control (T: temperature, ${ }^{\circ} \mathrm{C}$; $\mathrm{RH}$ : relative humidity, \%; WS: wind speed, $\mathrm{m} / \mathrm{s}$; RF: rainfall, $\mathrm{mm}$; SR: solar radiation, $\mathrm{MJ} / \mathrm{m}^{2}$ ).

Milk quality in the two percentile-groups $(\leq 50 \%$ and $>50 \%$ ) of each meteorological factor is shown in Figure 5 and 6 . In each of the seasons, DMY differed significantly $(P<$ 0.0001 ) between the two percentile groups (Figure 5), although the direction of the correlation with mean, min, and max T differed among seasons; in summer, DMY was significantly higher in the higher $T$ percentile than it was in the lower T percentile group. Similar differences in the direction of the effect were evident in the other meteorological variables. SCC was the variable that was least affected by $T$ (Figure 5), with significant differences between percentiles $(P<0.001)$ in winter, only, for mean, maximum, and minimum $\mathrm{T}$; however, $\mathrm{RH}$, wind speed, and $\mathrm{SR}$ significantly affected SCC in all seasons.

In the four seasons, fat, protein, and lactose content of milk differed significantly $(P<0.001)$ between the two percentile groups of the meteorological variables, except min $\mathrm{T}$ in autumn and WS in winter for fat content, $\mathrm{RH}$ in autumn for protein content, and WS in winter for lactose content (Figure 6).

\section{Discussion}

Weather on the day before a milk control had significant effects on DMY and milk chemical composition throughout the year, although the effects differed among seasons. Ambient T had a marked influence on milk yield in summer when milk production was highest in the upper percentile group for T. In other seasons, however, milk production was highest in the lower $\mathrm{T}$ percentile group. Peana et al (2017) reported a similar effect of T in winter and spring, such that, in winter, the optimal range of maximum temperature for milk production was $12-21^{\circ} \mathrm{C}$. In our study, in all seasons but summer, as $\mathrm{T}$ increased, milk yield decreased. In spring, the optimal mean T range $\left(6-20^{\circ} \mathrm{C}\right)$ for milk yield was similar to the optimal range but lower than the Tmax range $\left(24-30{ }^{\circ} \mathrm{C}\right)$ for grazing Sarda ewes in Sardinia (Peana et al 2007b). The upper limit of the optimal Tmax range $\left(26^{\circ} \mathrm{C}\right)$ in our study in summer was near or above the upper critical temperature $\left(25^{\circ} \mathrm{C}\right.$ ) for sheep (Ramón et al 2016). At temperatures $>25^{\circ} \mathrm{C}$, feed intake and physiological processes change significantly, which affects DMY (McDowell 1972); however, the thermal neutral zone is influenced by several other factors including environmental humidity, SR, WS, genotype, physiological state, thermal susceptibility, acclimation, and diet. At high $\mathrm{T}$, in an attempt to maintain body $\mathrm{T}$, animals exhibit physiological and behavioral responses that increase heat loss and reduce heat production, which occurred in Churra ewes in our study in summer and autumn. A reduction in feed intake by animals exposed to a hot environment contributes to the biological mechanism through which SR affects production and reproduction (Bernabucci et al 2010). Besides, RF and RH had a significant effect on the DMY and SCC of Churra ewes. Effects of thermal stress include an altered endocrine status, reductions in rumination and nutrient absorption, and increases in maintenance requirements (Collier et al 2006), which causes a net decrease in nutrient/energy availability. Reductions in energy intake coupled with increases in maintenance costs during heat stress cause a negative energy balance, likely, independent of the stage of lactation, and a bioenergetic state, which is similar to, but not to the same extent as the negative energy balance which occurs in early lactation. 

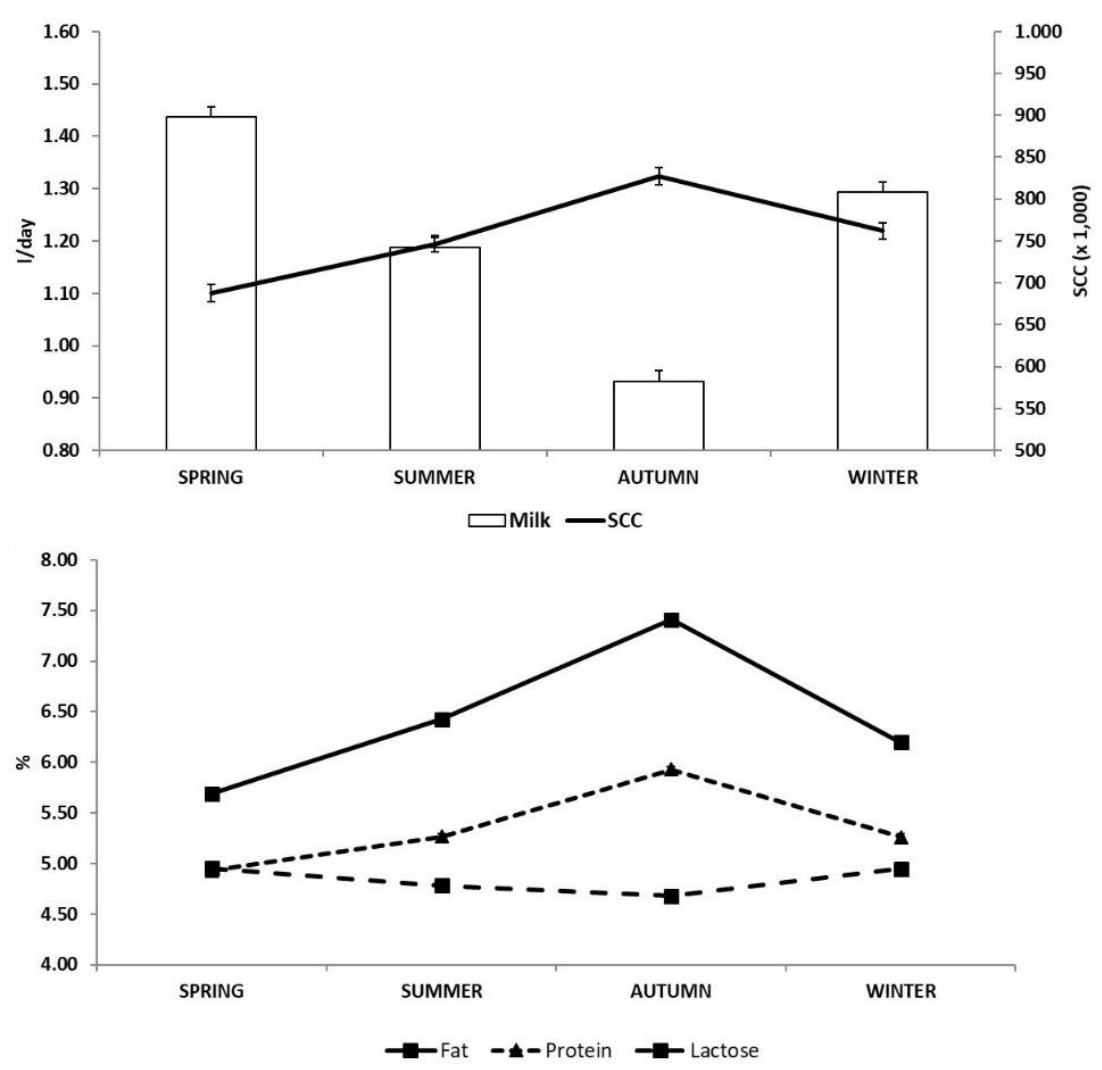

Figure 2 Mean ( \pm S.E.M.) daily milk yield (DMY) (I/d), Somatic Cell Count (SCC), and content (\%) of protein, fat, and lactose in milk from Churra ewes on 15 farms in Castilla y León, Spain, in 8 years (2009-2016). Individual DMY and quality measures were based on monthly, alternating controls.
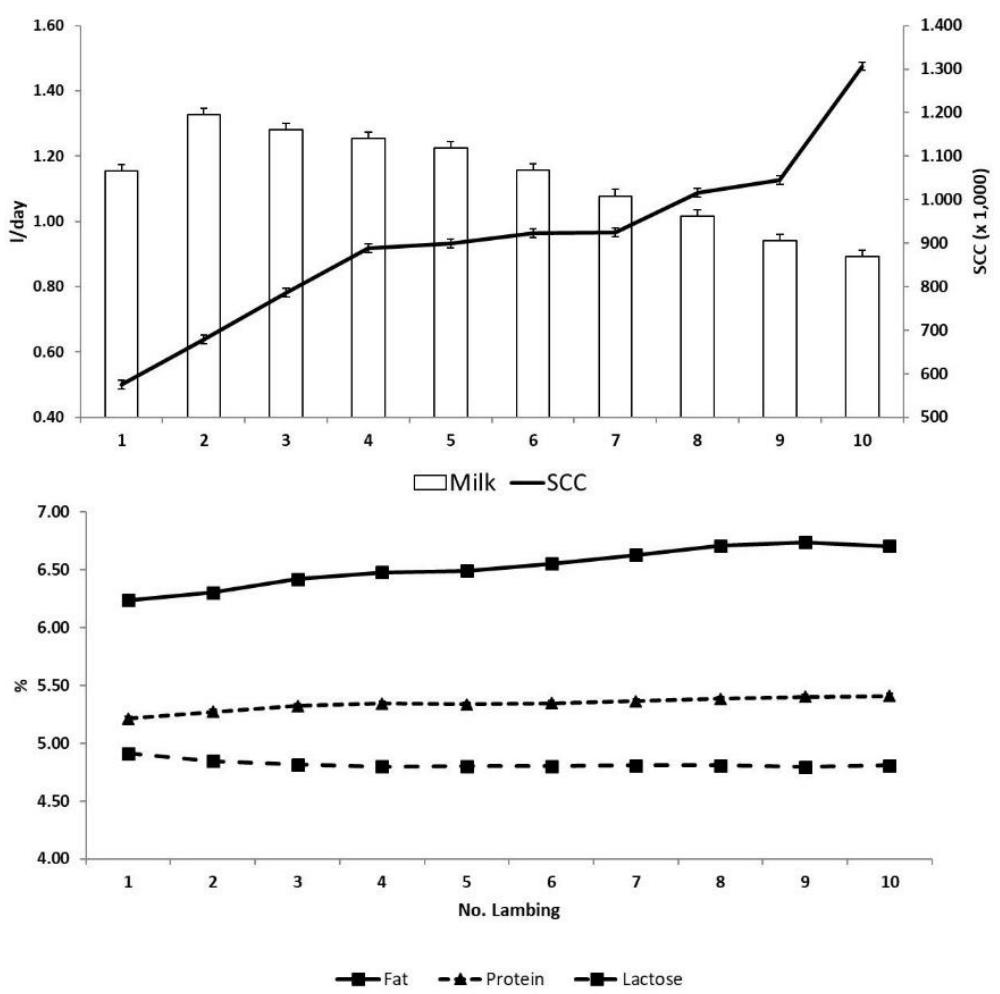

Figure 3 Mean ( \pm S.E.M.) daily milk yield (DMY) (I/d), Somatic Cell Count (SCC), and content (\%) of protein, fat, and lactose in milk from Churra ewes on 15 farms in Castilla y León, Spain (2009-2016) and the number of the lambing. Individual DMY and quality parameters were based on monthly, alternating controls. 

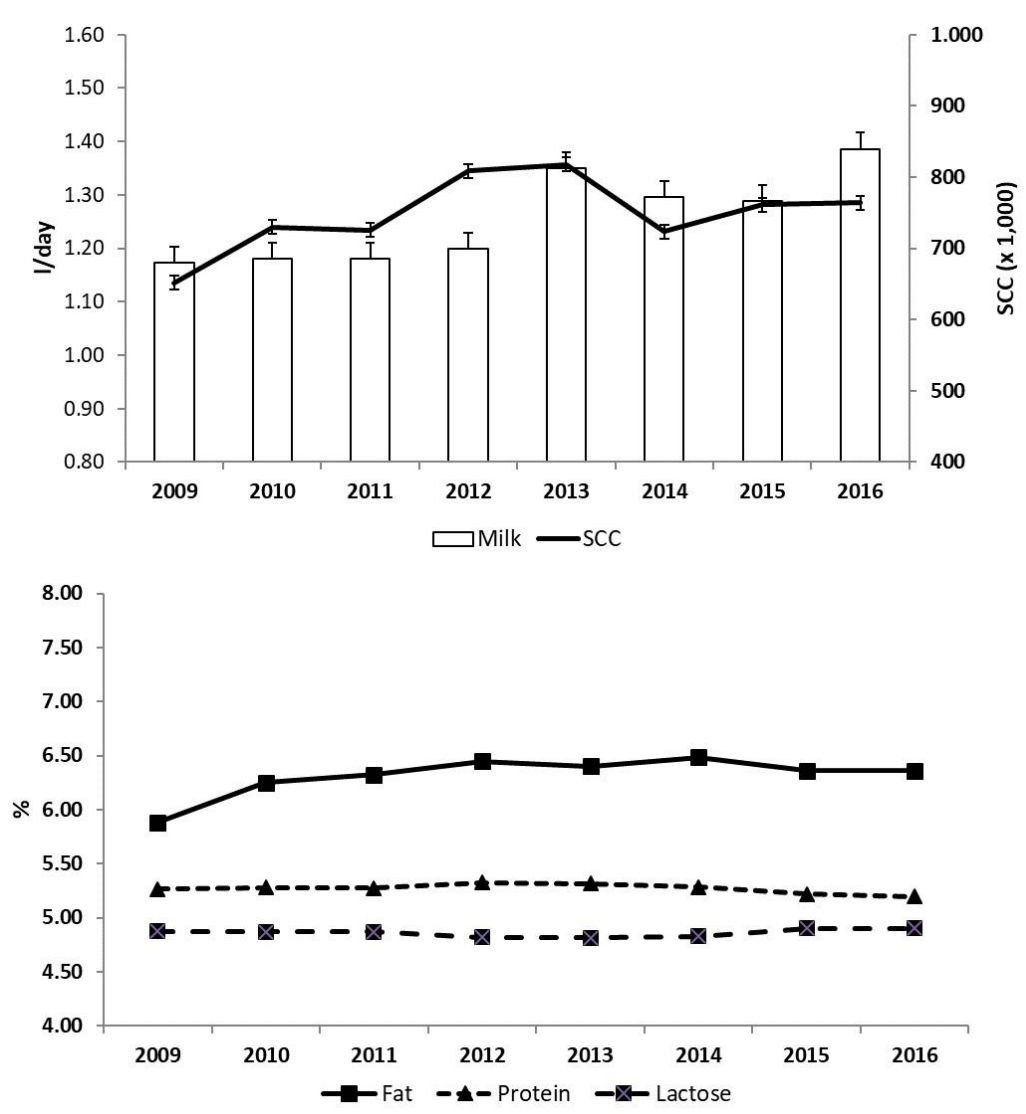

Figure 4 Mean ( \pm S.E.M.) daily milk yield (DMY) and Somatic Cell Count (SCC), and proportion of protein, fat, and lactose (\%) for the eight years under study, in milk from Churra ewes on 15 farms in Castilla y León, Spain (2009-2016). Individual DMY and quality measures were based on monthly, alternating controls.
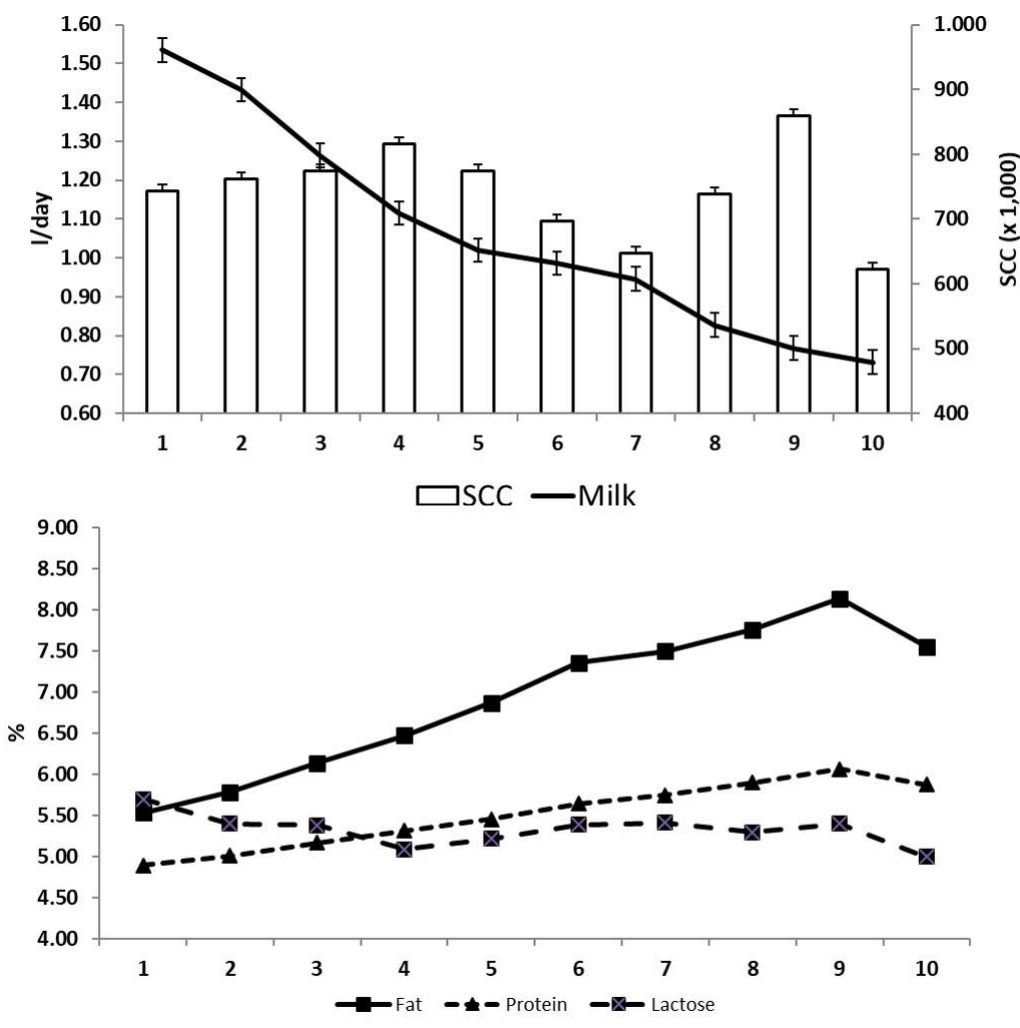

Figure 5 Mean ( \pm S.E.M.) daily milk yield (DMY) and Somatic Cell Count (SCC), and proportion of protein, fat, and lactose (\%) for the phase of lactation (monthly control), in milk from Churra ewes, on 15 farms in Castilla y León, Spain (2009-2016). Individual DMY and quality measures were based on monthly, alternating controls. 
$\mathrm{RH}$ had a significant effect on milk yield in Churra ewes, especially, in autumn. Peana et al (2017) reported a maximum reduction in milk yield in Sarda ewes in winter (9\%) and spring (5\%). In Churra ewes, WS affected DMY and chemical composition such that, above a threshold of WS, it was detrimental for milk production. Peana et al (2017) observed that WS $>2.5 \mathrm{~m} / \mathrm{s}$ or $>8 \mathrm{~m} / \mathrm{s}$ reduced milk production by $6 \%$ and $7 \%$, respectively. The negative effects of WS on DMY in summer and autumn occurred because the wind at that time $(<1.5 \mathrm{~m} / \mathrm{s})$ was lower than it was in spring and winter $(>2.0 \mathrm{~m} / \mathrm{s})$ and WS favors heat loss from the body surface through evaporation and convection (NRC, 1981). The beneficial effects of WS in spring ( $>2 \mathrm{~m} / \mathrm{s}$ ) were similar to those observed by Peana et al (2007c) who reported that milk yield was $15 \%$ higher in spring than it was summer. Both studies confirmed the beneficial effects of a light wind on the dissipation of excess body heat from the body surface through evaporation. SR affected DMY throughout the year and milk chemical composition, except fat content in summer, and protein and lactose content in spring. As in Peana et al (2017), SR had a significant positive effect on milk yield in spring, when SR was $>22 \mathrm{MJ} / \mathrm{m}^{2}$ in spring, but was associated with a reduction in DMY in autumn (35\%) and winter (8\%). The negative effects of SR $>24 \mathrm{MJ} / \mathrm{m}^{2}$ on the DMY of grazing Sarda ewes in autumn (Peana et al 2017) suggest that, above certain radiation levels, it is very important to initiate management practices that prevent the detrimental effects of high SR on milk yield. Di Grigoli et al (2009) and Bonanno et al (2013) found that milk production was higher in sheep that grazed at night than it was in sheep that grazed during the day or were kept indoors, especially in high $\mathrm{T} / \mathrm{RH}$ conditions ( $\mathrm{THI}>90$ ). In hot climates, shade is essential for maintaining efficiency in milk production and reproduction and can be essential for livestock survival in moderate Mediterranean conditions in summer and autumn, the shade might not be essential to survival, but it is important for ensuring well-being and performance (Armstrong 1994; Brown-Brandl et al 2001; Caroprese et al 2012).

RF affected DMY, SCC, and milk chemical composition in Churra ewes such that effective RF $>1 \mathrm{~mm} /$ day was accompanied by a significant decrease in milk production in autumn. The negative effects of an effective RF $>2 \mathrm{~mm} / \mathrm{d}$ on DMY in autumn occurred because RF increases body heat loss (direct effect) and coincides with a reduction in WS, and limits or prevents feed ingestion (indirect effect) (Young and Degen 1981). The effects of WS and RF in winter differed from those of Peana et al (2007a), who found that WS and RF had no significant effects on sheep milk production in winter. Peana et al (2007b) reported that a 2-day cumulative $\mathrm{RF}>6 \mathrm{~mm}$ corresponded with a $23 \%$ reduction in milk yield in springsummer, similar to the $>15 \%$ reduction in spring observed in our study.

The average DMY in our study was similar to those reported in the same breed (Fernandez et al 1995), and in the Comisana (Sebi et al 2000), and Chios breeds (Ploumi et al 1998), but was higher than were those reported in the
Manchega and East Friesian breeds (Angeles-Hernandez et al 2017) and crossed ewes (Mioč et al 2009; Robles Jimenez et al 2020; Angeles-Hernandez et al 2018). Milk yields in Churra ewes were lower than were those in specialized dairy breeds such as Awassi, Lacaune, and Assaf (Elvira et al 2013; Gootwine and Goot 1994; Gootwine and Pollot 2000), and the differences are mainly because of genetic factors.
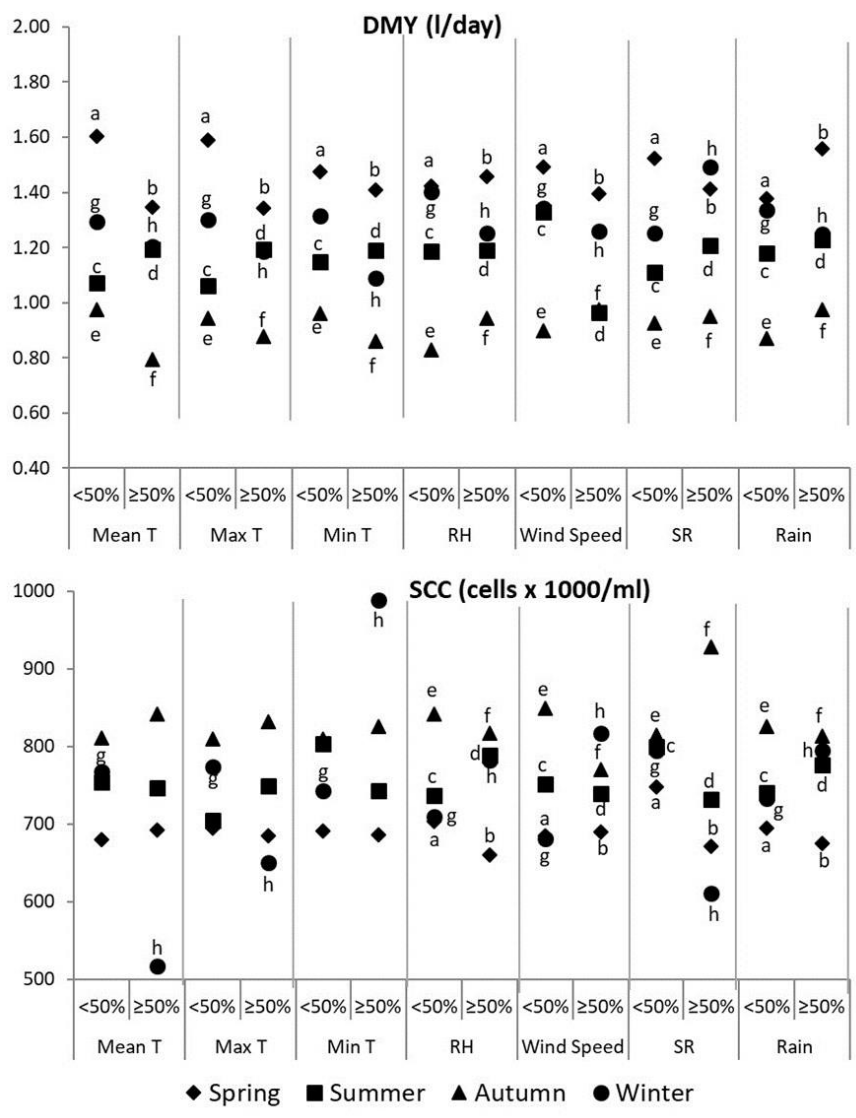

Figure 6 Mean daily milk yield (DMY) and Somatic Cell Count (SCC) of Churra ewes on 15 farms in Castilla y León, Spain, in the two percentiles $(<50 \%$ or $\geq 50 \%)$ of mean, maximum (max), and minimum ( $\mathrm{min}$ ) temperature $(\mathrm{T})$, relative humidity $(\mathrm{RH})$, wind speed, solar radiation (SR), and rainfall on the day before milk control $(a, b$; c,d; e,f; g,h indicate $P<0.05$ ).

In our study, the season of lambing has a significant effect on milk production. Similarly, Ruiz et al (2000) and Gabiña et al (1993) reported that the highest DMY occurred in winter. In our study, the highest DMY occurred in winter and spring, and the lowest was in autumn. Similarly, Palacios and de la Fuente (2007) found that DMY in Castellana sheep was highest in spring (January-April) and, in Assaf sheep, the period of high production was December-April.

Similar to our study, Gabiña et al (1993) found that milk production in the Latxa breed was positively correlated with age and the number of lambings. Similarly, studies have shown that DMY is higher in multiparous ewes up to the sixth lactation than it is in primiparous ewes (Ruiz et al 2000, Robles-Jimenez et al 2020; Rovai et al 1999; Abecia and Palacios 2017), which might be due in part to a lower provision of nutrients to the mammary gland used to synthesize milk components because primiparous animals 
have to use their nutrients for their growth in addition to lactation (Lérias et al 2014). Besides, younger ewes have lower body weight, body condition score, and body reserves than do older ewes (González-García et al 2015, AngelesHernandez et al 2017).

In our study, the chemical composition of the milk differed by the number of births, which was positively associated with fat content. Sevi et al (2000) observed the same phenomenon in the Comisana breed. Our study suggests that differences in secretory cell dynamics are involved in the effects of animal age and season on DMY. In small ruminants, the alveoli and secretory structures that develop in lactation do not disappear entirely during involution and, in addition to those that form in the subsequent lactation, increase udder volume, especially, the secretory parenchyma tissue (Lérias et al 2014), which might contribute to the reduction in DMY after the sixth lactation.

In our study and studies of the Castellana, Assaf (Palacios and de la Fuente 2007), and Valle of Belice (Riggio et al 2009) breeds, milk quality, and quantity differed significantly among farms and years. Differences in weather and its effects on the availability of nutritional resources might have contributed to differences among years (Ruiz et al, 2000). Although the 15 farms in our study had similar feeding regimes, other management factors such as weaning management (Angeles Hernandez et al 2018) and the age structure of the flock might have contributed to the effect of the farm on milk production. Riggio et al (2009) concluded that the flock-year-season combination effect explained $27 \%$ of the variation in milk production in Valle del Belice dairy sheep.

Regarding the stage of lactation, the results of the present study are in agreement with our previous experiments, where we concluded that the effects of meteorological conditions on milk yield in sheep cannot be understood without assessing production among milking periods in the same year and the phases of lactation, especially if milking periods are long (Abecia et al, 2017).

An important finding of our study was the positive correlation between the number of lambings and SCC, which are a reflection of the inflammatory response to an intramammary infection or another trigger of the immune system, or a physiological phase of lactation (Albenzio et al 2019), and is an index of animal health. Similar to our study, Riggio et al (2009) reported that the effect of age at first lambing resulted in an increase in culling rate with age, and had assigned ewes to one of the following three classes; viz., 1 , SCC $\leq 500,000$ cells $\mathrm{mL}^{-1}, 2,500,000$ cells $\mathrm{mL}^{-1}<\mathrm{SCC}<1$ million cells $\mathrm{mL}^{-1}$, and 3, SCC $\geq 1$ million cells $\mathrm{mL}^{-1}$. Ewes in class 2 or 3 are at the highest risk of being culled. In our study, ewes that had $>8$ lambings, which coincided with a reduced DMY and increased SSC, were at a higher risk of being culled. In many countries, the current milk payment system for sheep is based on milk yield and SCC, and flocks that have a higher than average number of aged ewes will see their incomes diminish.

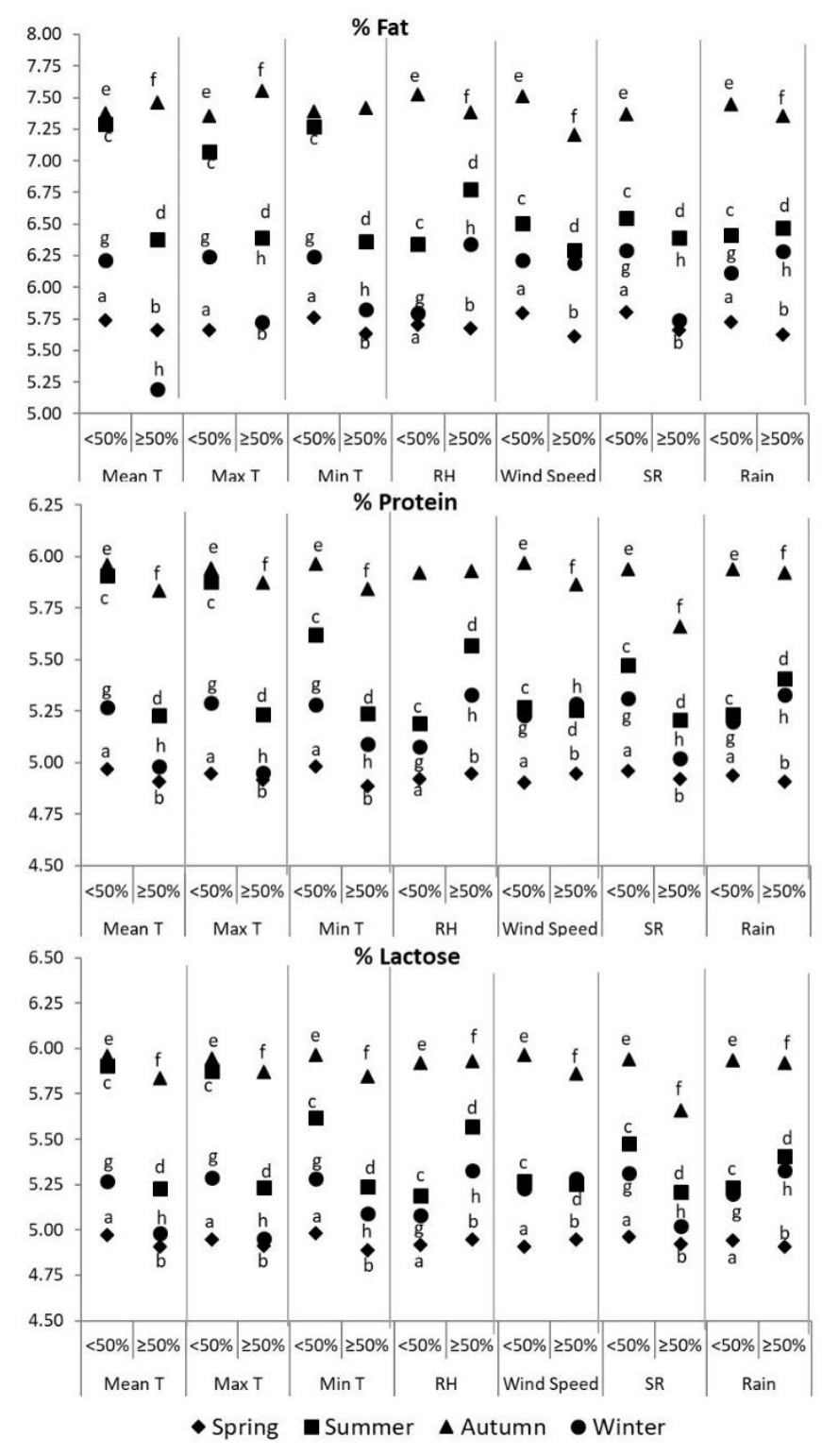

Figure 7 Mean proportion of fat, protein, and lactose (\%) of Churra ewes on 15 farms in Castilla y León, Spain, and the percentile $(<50 \%$ or $\geq 50 \%$ ) of the mean, maximum (max), and minimum ( $\min$ ) temperature $(\mathrm{T})$, relative humidity $(\mathrm{RH})$, wind speed, solar radiation $(S R)$, and rainfall the day before milk control $(a, b ; c, d ; e, f ; g, h$ indicate $P<0.05$ ).

\section{Conclusions}

In this study, Churra ewes that lambed in spring produced more milk than did ewes that lambed in summer or autumn, and the positive effects of age on milk yield increased until the sixth lambing. Weather factors affected milk production and quality, although the direction of the effects differed among seasons. Knowledge about the effects of meteorological factors can be used to formulate management strategies that enhance milk production in dairy sheep, by emphasizing the importance of adopting new management practices. The use of shelters, and appropriate ventilation, can reduce the negative effects of excessive cold in winter and heat in summer on the milk yield of dairy sheep in the Mediterranean region. 


\section{Acknowledgments}

We thank Bruce MacWhirter for the English revision of the manuscript.

\section{Conflict of Interest}

The authors declare that they have no conflict of interest.

\section{Funding}

MR Gonzalez Ronquillo was supported by a fellowship ("Movilidad de Profesores extranjeros en virtud de convenios de cooperación") from the University of Salamanca, Spain.

\section{References}

Abecia JA, Garcia A, Castillo L, Palacios C (2017) The effects of weather on milk production in dairy sheep vary by month of lambing and lactation phase. Journal of Animal Behaviour and Biometeorology 5:56-63.

Abecia JA, Palacios C (2017) Ewes giving birth to female lambs produce more milk than ewes giving birth to male lambs. Italian Journal of Animal Science 17:736-739.

Abdela N, Jilo K (2016) Impact of climate change on livestock health: A review. Global Veterinary 16:419-424.

Albenzio M, Figliola L, Caroprese M, Marino R, Sevi A, Santillo A (2019) Somatic cell count in sheep milk. Small Ruminant Research 176:24-30.

Angeles-Hernandez J, Radic Schilling S, Vera Arias M, Echeverría Pérez R, Castelán Ortega O, Ramirez Perez A, Gonzalez-Ronquillo M (2017) Effect of live weight pre and post-lambing on milk production of East Friesian sheep. Italian Journal of Animal Science 17:184-194.

Angeles-Hernandez JC, Pollott JE, Albarran Portillo B, Ramírez-Perez AH, Lizarazo Chaparro A, Castelan Ortega OA, Gonzalez Ronquillo M (2018) The application of a mechanistic model to analyze the factors that affect the lactation curve parameters of dairy sheep. Small Ruminant Research 64:5863.

Armstrong DV (1994) Heat stress interaction with shade and cooling. Journal of Dairy Science 77:2044-2050.

Behera R, Chakravarty AK, Sahu A, Kashyap N, Rai S, Mandal A (2017) Identification of best temperature humidity index model for assessing impact of heat stress on milk constituent traits in Mirrah buffaloes under subtropical climatic conditions of Northern India. Indian Journal of Animal Research 52:13-19.

Bernabucci U, Lacetera N, Baumgard LH, Rhoads RP, Ronchi B, Nardone A (2010) Metabolic and hormonal acclimation to heat stress in domesticated ruminants. Animal 4:1167-1183.

Bonanno A, Di Grigoli A, Tornambè G (2013) La destagionalizzazione della produzione lattiero casearia degli ovini in Sicilia (Out-of-season dairy sheep production in Sicily). Large Animal Review 19:151-154.

Brown-Brandl TM, Eigenberg RA, Hahn GL, Nienaber JA (2001) Correlations of respiration rate, core body temperature and temperatures for shaded and non-shaded cattle. In: ASAE (ed) Proceedings of the 6th International Livestock Environmental Symposium. Louisville, Kentucky, pp. 448-454.

Caroprese M, Albenzio M, Bruno A, Fedele V, Santillo A, Sevi A (2011) Effects of solar radiation and flaxseed supplementation on milk production and fatty acid profile of lactating ewes under high ambient temperature. Journal of Dairy Science 94:3856-3867.

Caroprese M, Albenzio M, Bruno A, Annicchiarico G, Marino R, Sevi A (2012) Effects of shade and flaxseed supplementation on the welfare of lactating ewes under high ambient temperatures. Small Ruminant Research 102:177185.

Curtis SE (1983) Environmental management in animal agriculture. lowa State Press, USA.

Di Grigoli A, Todaro M, Di Miceli G, Alicata ML, Cascone G, Bonanno A (2009) Milk production and physiological traits of ewes and goats housed indoor or grazing at different daily timing in summer. Italian Journal of Animal Science 8:616-618.

Elvira L, Hernandez F, Cuesta P, Cano S, Gonzalez-Martin JV, Astiz S (2013) Accurate mathematical models to describe the lactation curve of Lacaune dairy sheep under intensive management. Animal 7:1-9.

Fernandez G, Alvarez P, San Primitivo F, de la Fuente LF, 1995) Factors affecting variation of udder traits of dairy ewes. Journal of Dairy Science 78:842-849.

Gabiña D, Arrese F, Arranz J, Beltrán de Heredia I, 1993) Average milk yield and environmental effects on Latxa sheep. Journal of Dairy Science 76:11911198.

González-García E, Tesniere A, Camous S, Bocquier F, Barillet F, Hassoun P (2015) The effects of parity, litter size, physiological state, and milking frequency on the metabolic profile of Lacaune dairy ewes. Domestic Animal Endocrinology 50:32-44.

Gootwine E, Pollott GE (2000) Factors affecting milk production in Improved Awassi dairy ewes. Animal Science 71:607-615.

Gootwine E, Goot H, 1994) Lamb and milk production of Awassi and EastFriesian sheep and their crosses under Mediterranean environment. Small Ruminant Research 20:255-260.

Hernandez F, Elvira L, Gonzalez-Martin JV, Gonzalez-Bulnes A, Astiz S (2011) Influence of age at first lambing on reproductive and productive performance of Lacaune dairy sheep under an intensive management system. Journal of Dairy Research 78:160-167.

IDF (2010) Milk, cream and evaporated milk. In: Determination of total solids content. Standard 021. International Dairy Federation. Brussels, Belgium.

IDF (2001) Milk. Determination of nitrogen content. Part 5: Determination of protein-nitrogen content. In: Standard 020-5. International Dairy Federation. Brussels, Belgium.

IDF (2008) Milk. Determination of fat content. Gerber butyrometers. In: Standard 105. International Dairy Federation. Brussels, Belgium.

IBM Corp. Released (2017) IBM SPSS Statistics for Windows, Version 25.0. Armonk, NY: IBM Corp.

ICAR (2016) International Agreement of Recording Practices. Roma, Italy.

Laporta J, Fabris TF, Skibiel AL, Powell JL, Hayen MJ, Horvath K, Miller-Cushon EK, Dahl GE (2017) In utero exposure to heat stress during late gestation has prolonged effects on the activity patterns and growth of dairy calves. Journal of Dairy Science 100:2976-2984.

Lérias JR, Hernández-Castellano LE, Suárez-Trujillo A, Castro N, Pourlis A, Almeida AM (2014) The mammary gland in small ruminants: major morphological and functional events underlying milk production -a review. Journal of Dairy Research 81:304-318.

NRC (1981) Effect of environment on nutrient requirements of domestic animals. National Academy Press, Washington, DC.

McDowell RE (1972) The animal body in warm environment. In: Freeman WH and Co (ed) Improvement of livestock production in warm climates. San Francisco, California, p. 65.

Mioč B, Prpić Z, Antunac N, Antunović Z, Samaržija D, Vnučec I, Pavić V (2009) Milk yield and quality of Cres sheep and their crosses with Awassi and East Friesian sheep. Mljekarstvo 59:217-224.

Nasr MAF, El-Tarabany MS (2017) Impact of three THI levels on somatic cell count, milk yield and composition of multiparous Holstein cows in a subtropical region. Journal of Thermal Biology 64:73-77.

Mylostyvyi R, Chernenko O (2019) Correlations between Environmental factors and milk production of Holstein cows. Data 4:1-8.

Nudda A, Atzori AS, Correddu F, Battacone G, Lunesu MF, Cannas A, Pulina G (2019) Effects of nutrition on main components of sheep milk. Small Ruminant Research 184:106015.

Palacios C, de la Fuente LF (2007) Análisis de factores de variación de la producción láctea en ganado ovino de las razas Castellana y Assaf. ITEA-Información Técnica Económica Agraria 28:303-305.

Peana I, Dimauro C, Carta M, Gaspa M, Fois G, Cannas A (2007a) Cold markedly influences milk yield of Sardinian dairy sheep farms. Italian Journal of Animal Science 6:580. 
Peana I, Dimauro C, Carta M, Gaspa M, Fois G, Cannas A (2007b) Effects of heat stress on milk yield in Sardinian dairy sheep farms. Italian Journal of Animal Science 6:581.

Peana I, Fois G, Cannas A (2007c) Effects of heat stress and diet on milk production and feed and energy intake of Sarda ewes. Italian Journal of Animal Science 6:577-579.

Peana I, Dias Francesconi AH, Dimauro C, Cannas A, Sitzia M (2017) Effect of winter and spring meteorological conditions on milk production of grazing dairy sheep in the Mediterranean environment. Small Ruminant Research 153:194-208.

Ploumi K, Belibasaki S, Triantaphyllidis G (1998) Some factors affecting daily milk yield and composition in a flock of Chios ewes. Small Ruminant Research 28:89-92.

Ramón M, Díaz C, Pérez-Guzman MD, Carabaño MJ (2016) Effect of exposure to adverse climatic conditions on production in Manchega dairy sheep. Journal of Dairy Science 99:5764-5779.

Riggio V, Maizon DO, Portolano B, Bovenhuis H, van Arendonk JAM (2009) Effect of somatic cell count level on functional longevity in Valle del Belice dairy sheep assessed using survival analysis. Journal of Dairy Science 92:6160-6166.

Robles-Jimenez LE, Angeles-Hernandez JC, Palacios C, Abecia JA, Naranjo A, Osorio Avalos J, Gonzalez-Ronquillo, M (2020) Milk production of Lacaune sheep with different degrees of crossing with Manchega sheep in a commercial flock in Spain. Animals 20:520.
Rovai M, Such X, Piedrafita J, Caja G, Pujol MR (1999) Evolution of mammary morphology traits during lactation and its relationship with milk yield of Manchega and Lacaune dairy sheep. In: Barillet F, Zervas NP (eds) Milking and milk production of dairy sheep and goats. EAAP Publication No. 95. Wageningen Pers, Wageningen, The Netherlands, pp. 107-109.

Ruiz R, Oregui LM, Herrero M (2000) Comparison of models for describing the lactation curve of Latxa sheep and an analysis of factors affecting milk yield. Journal of Dairy Science 83:2709-2719.

Sevi A, Taibi L, Albenzio M, Muscio, A., Annicchiarico, G (2000) Effect of parity on milk yield, composition, somatic cell count, renneting parameters and bacteria counts of Comisana ewes. Small Ruminant Research 37:99-107.

Sevi A, Caroprese M (2012) Impact of heat stress on milk production, immunity and udder health in sheep: A critical review. Small Ruminant Research 107:1-7.

Sejian V, Bhatta R, Gaughan JB, Dunshea FR, Lacetera N (2018) Review: Adaptation of animals to heat stress. Animal 12:431-444.

Young BA, Degen AA (1981) Thermal influences of ruminants. In: Clark JA (ed) Environmental aspects of housing for animal production. Butterworths, London, pp. 167-180. 